\title{
Самородный цинк г. Коашва, Хибинский массив
}

\author{
Николаев А.П. ${ }^{1}$, Пахомовский Я.А. ${ }^{2}$, Селиванова Е.А. ${ }^{2}$ \\ ${ }^{1}$ Музейно-выставочный иентр ОАО «Anатит», Кировск, apnikolaev@phosagro.ru \\ 2 Геологический институт КНЦ РАН, Anamumbl, pakhom@geoksc.apatity.ru
}

Аннотация. В статье даётся описание первой находки самородного цинка в Хибинском массиве в срастании с самородным железом. Возникновение ассоциации самородных металлов с углеводородами свидетельствуют о существовании локальных восстановительных условий в натролитовом ядре микроклин-эгиринсодалит- натролитовой жилы.

Ключевые слова: самородные элементы, цинк, Хибинский массив, Коашва, железо.

\section{Native zinc of Koashva Mountain, Khibiny massif}

\author{
Nikolaev A.P. ${ }^{1}$, Pakhomovsky Ya.A. ${ }^{2}$, Selivanova E.A. ${ }^{2}$ \\ ${ }^{1}$ Museum and exhibition centre of JSC «Apatit»,Kirovsk, apnikolaev@phosagro.ru \\ ${ }^{2}$ Geological institute KSC RAS, Apatity,pakhom@geoksc.apatity.ru
}

\begin{abstract}
The article describes the first discovery of native zinc in the Khibiny massif in coalescence with native iron. Associations of native metals with hydrocarbons indicate the existence of reducing conditions in the natrolite nucleus of microcline-aegirin-sodalite vein.
\end{abstract}

Key words: Koashva, Khibiny massif, native zinc, native iron.

В породах Хибинского массива Кольского полуострова в настоящее время известно пять самородных элементов: графит (Бонштедт и др., 1937; Зезин, Соколова, 1967; Костылева-Лабунцова и др., 1978; Шлюкова, 1986), железо, связаннное с ороговикованными ксенолитами вулканогенноосадочных пород (Дудкин, Меньшиков, 1983) и содалит-ортоклазовыми жилами в указанных ксенолитах (Шлюкова, 1986), а также установленные В.Н. Яковенчуком с коллегами висмут, свинец и сера (Яковенчук и др., 2004; Yakovenchuk et al., 2005). В породах Ловозёрского массива в виде самородных элементов обнаружены свинец, сурьма, сера, цинк (Яковенчук и др., 2004; Пахомовский и др., 2005) и графит (Пеков, 2001).

Самородный цинк хоть и редок, но не уникален. Он встречается в разнообразных обстановках, но весьма примечательно его присутствие в щелочных ассоциациях. Природный цинк на Кольском полуострове ранее был установлен в уссингитовой жиле «Сиреневая» г. Аллуайв соседнего Ловозёрского массива в виде мелких, до 0.8 мм в диаметре, отдельных чешуек светло-серого цвета, нарастающих в пустотах на уссингит или вкрапленных в его массу на границе с кристаллами микроклина в ассоциации с полурастворенными зернами сфалерита, виллиомитом, вуоннемитом, макатитом и линтиситом (Яковенчук и др., 2004; Пахомовский и др., 2005).

Авторами самородный цинк был обнаружен в образце из микроклин-эгирин-содалит- натролитовой жилы, вскрытой в 2007 году в северо-западной части карьера г. Коашва Хибинского массива на абсолютной отметке +110 м. Жила, подробно описанная в работах В.Н. Яковенчука с коллегами (Yakovenchuk et al., 2010a, Yakovenchuk et al., 2010b) представляет собой тело размером около $2 \times 0.5$ м в плане, секущее уртиты вблизи контакта с рудным телом. В его центральной части находится линза размером около $0.6 \times 0.3 \times 0.2$ м, обогащенная хлорбартонитом и астрофиллитом. Эндоконтакты жилы - существенно эгириновые в виде так называемых эгириновых «бомб» до 0.3 м в диаметре. Значительный объем жилы занимали: фторапатит, лоренценит с развитым по нему виноградовитом, бурбанкит, флюорит, органика в виде многочисленных каплевидных включений в натролите, более редкие сфалерит, тайниолит, твердые углеводороды и другие минералы - всего около 20 видов, включая впервые найденные в Хибинах орикит и эльпасолит, а также новые минералы - стронциофлюорит (Yakovenchuk et al., 2010a) и полежаеваит-(Cе) (Yakovenchuk et al., 2010b). 

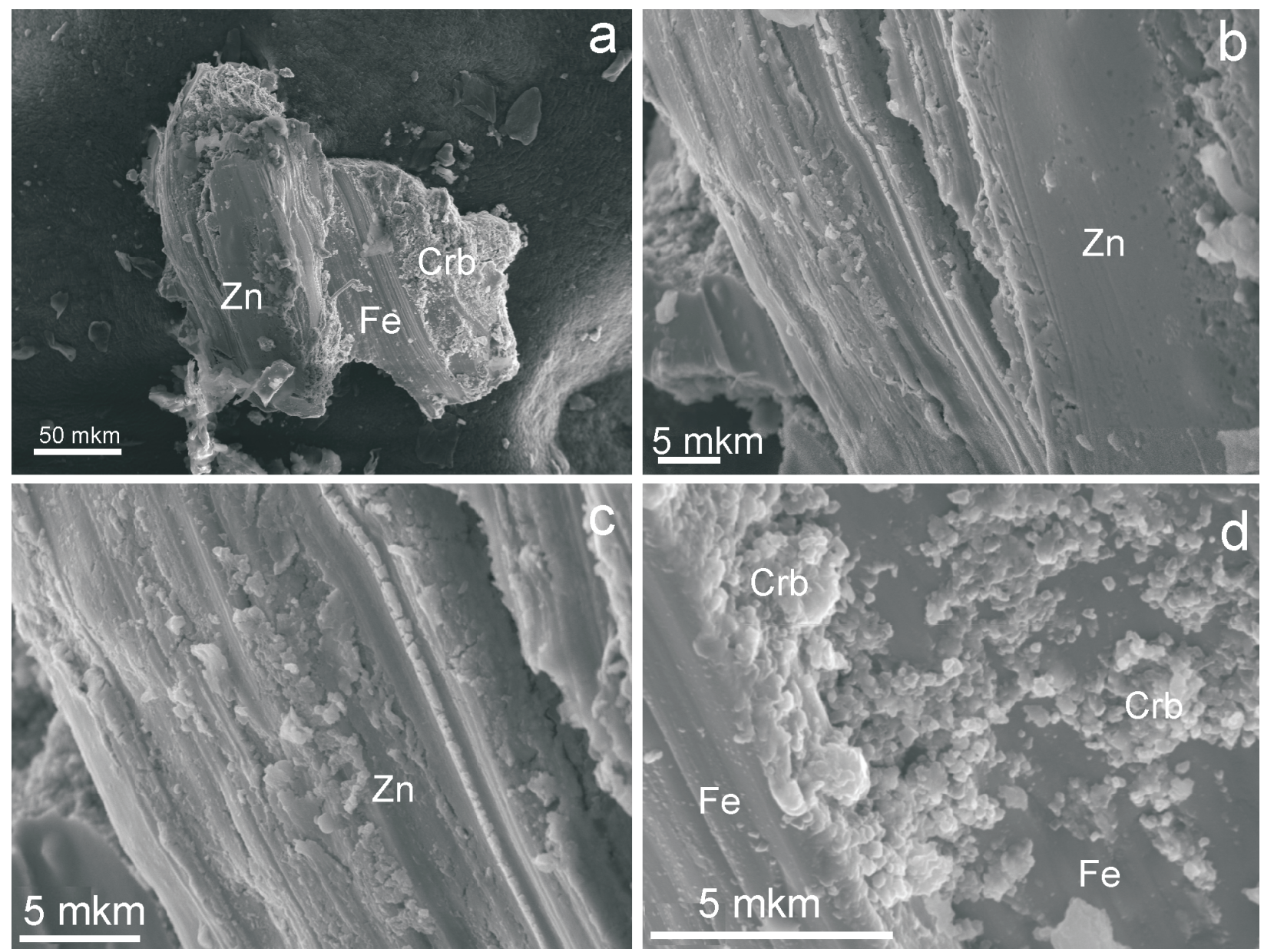

Рис. 1. Сросток самородных железа и цинка $(a)$, морфология выделения самородного цинка $(b$ и $c)$ и сростки сферолитов карбоната цинка $(\mathrm{Crb})$ на поверхности самородного железа $(d)$. Изображения во вторичных электронах.

Fig. 1. Aggregate of natural iron and zinc ( $a$ ), morphology of native zinc plates $(b$ and $c$ ) and rinds of spherulites on iron surface $(d)$. Secondary-electron (SE) images.
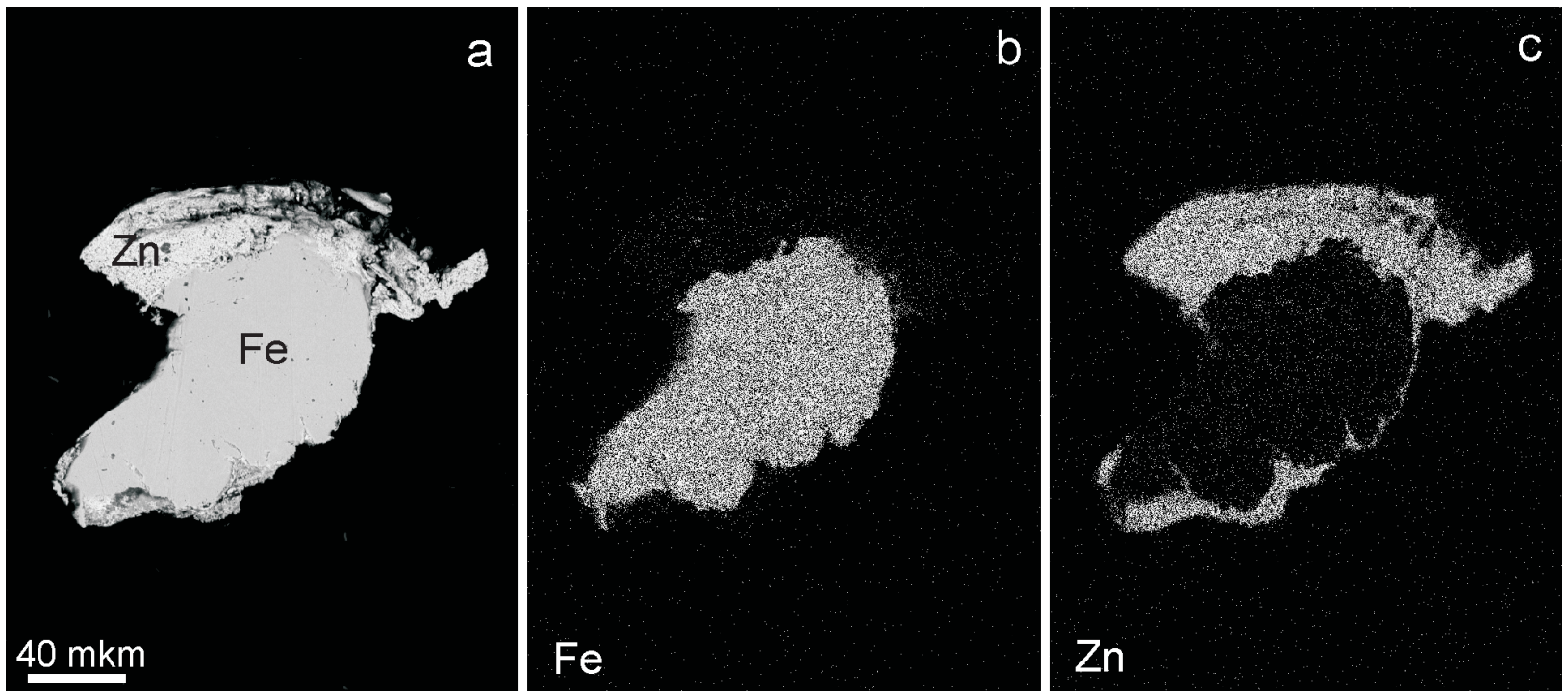

Рис. 2. Изображение полированного сечения сростка самородных цинка и железа в обратно-рассеянных электронах $(a)$ и характеристическом излучении железа $(b)$ и цинка $(c)$.

Fig. 2. Image of a polished section of native iron and zinc aggregate in back-scattered electrons (BSE) (a) and characteristic X-ray radiation $\mathrm{Fe}(b)$ and $\mathrm{Zn}(c)$. 
Выделение цинка в форме укороченной булавы с ярким металлическим блеском встречено всего лишь в одном месте, в пустотке размером около 1 х 0.5 мм в натролите. Размер выделения около $0.8 \times 0.3$ мм и, как оказалось, цинк находится в нем в срастании с самородным железом (рис. 1). Изучение полированного сечения металлов (рис. 2) свидетельствует о более поздней кристаллизации цинка, который, кроме собственных тонкопластинчатых выделений, в виде тонких чешуек нарастает на железо. Оба металла покрыты сыпью и корочками мельчайших сферолитов карбоната цинка (рис. 1 с), вероятно смитсонита, более точную диагностику которого выполнить не удалось.

Химический состав образца, выполненный при использовании энергодисперсионной системы Quantax 200, установленной на сканирующем электронном микроскопе LEO-1450, показал отсутствие каких-либо примесных элементов как в цинке, так и в железе.

Наиболее частой примесью в самородном цинке является медь, так, цинк из медных руд рудника Дульсинея де Льямпос, Копьяпо, Чили содержит медь в количестве до 0.12 мас. \% (Clark, Sillitoe, 1970), а цинк из Ловозерского массива - до 2.2 мас. \%. Самородный цинк без примесей, определяемых при помощи микрозондового анализа, также встречается, он установлен, например, в породах многих трапповых тел Сибирской платформы (Округин и др., 1981).

Появление самородных железа и цинка, особенно в ассоциации с твердыми углеводородами связано с восстановительными условиями среды минералообразования в условиях существенного дефицита кислорода и серы, что отмечалось ранее для других самородных металлов из Хибинского и Ловозёрского массивов (Яковенчук и др., 2004). Появление на поверхности металлов карбоната или карбонат-гидроксида цинка, возможно, в результате изменения металлического цинка, указывает на очередное изменение условий кристаллизации в сторону повышения окислительного потенциала среды.

Работа выполнена в рамках темы НИР № 0226-2019-0051.

\section{Литература}

1. Бонштедт Э.М. и др. Минералы Хибинских и Ловозерских тундр. М.-Л. Изд-во: АН СССР. 1937. 563 с.

2. Дудкин О.Б., Меньшиков Ю.П. Минералогическое изучение кольских щелочных массивов и его практическое значение // Записки ВМО. 1983. № 5. С. 513-520.

3. Зезин Р.Б., Соколова М.Н. Макропроявления углеродистых веществ в гидротермальных образованиях Хибинского массива // Доклады АН СССР. 1967. Т. 177. № 4. С. 921-924.

4. Костылева-Лабунцова Е.Е. и др. Минералогия Хибинского массива. Том. 1.: Магматизм и постмагматические преобразования. Москва: Наука. 1978. 227 с.

5. Округин А. В., Олейников Б. В., Заякина Н. В., Лескова Н. В. Самородные металлы в траппах Сибирской платформы // Записки ВМО. 1981. № 2. С. 186-204.

6. Пахомовский Я.А., Яковенчук В.Н., Иванюк Г.Ю., Меньшиков Ю.П. Новые данные по минералогии жилы Сиреневая, г. Аллуайв, Ловозерский массив // Минералогия во всем пространстве сего слова. Труды II Ферсмановской научной сессии Кольского отделения РМО, посвященной 140-летию со дня рождения В. Рамзая. Апатиты: Изд-во: «К\&М». 2005. С. 72-75.

7. Пеков И.В. Ловозерский массив: история исследования, пегматиты, минералы. М. Изд-во: Земля. 2001. 464 с.

8. Шлюкова 3.В. Минералогия контактных образований Хибинского массива. М. Изд-во: Наука. 1986. 144 с.

9. Яковенчук В.Н., Иванюк Г.Ю., Пахомовский Я.А., Михайлова Ю.А. Самородные элементы Хибинского и Ловозерского массивов // Минералогия во всем пространстве сего слова. Ч.І. Труды I Ферсмановской научной сессии Кольского отделения Российского минералогического общества, посвященной 120-летию со дня рождения А.Е. Ферсмана и А.Н. Лабунцова. г. Апатиты, 22-23 апреля 2004 г. 2004. С. 37-38.

10. Clark, A.H., Sillitoe, R.H. Native zinc and $\alpha-\mathrm{Cu}, \mathrm{Zn}$ from Mina Dulcinea de Llampos, Copiapó, Chile // American Mineralogist. 1970. V. 55. P. 1019-1021.

11. Yakovenchuk V.N., Ivanyuk G.Yu., Pakhomovsky Ya.A., Men'shikov Yu.P. (Ed. F. Wall) Khibiny. Laplandia Minerals. Apatity. 2005. 467 p.

12. Yakovenchuk V.N., Ivanyuk G.Yu., Pakhomovsky Ya.A., Selivanova E.A., Korchak Yu.A., Nikolaev A.P. Strontiofluorite, $\mathrm{SrF}_{2}$, a new mineral species from the Khibiny massif, Kola Peninsula, Russia // The Canadian Mineralogist. 2010. V. 48. 6. P. 1487-1492.

13. Yakovenchuk V.N., Selivanova E.A., Ivanyuk G.Yu., Pakhomovsky Ya.A., Korchak Yu.A., Nikolaev A.P. Polezhaevaite-(Ce), $\mathrm{NaSrCeF}_{6}$, a new mineral from the Khibiny massif (Kola Peninsula, Russia) // American Mineralogist. 2010. V. 95. P. 1080-1083. 